\title{
Explaining variation in the role of the EU Council Secretariat in first and second pillar policy-making
}

Citation for published version (APA):

Dijkstra, H. (2010). Explaining variation in the role of the EU Council Secretariat in first and second pillar policy-making. Journal of European Public Policy, 17(4), 527-544. [922332328].

https://doi.org/10.1080/13501761003673526

Document status and date:

Published: 18/05/2010

DOI:

10.1080/13501761003673526

Document Version:

Accepted author manuscript (Peer reviewed / editorial board version)

\section{Document license:}

Unspecified

\section{Please check the document version of this publication:}

- A submitted manuscript is the version of the article upon submission and before peer-review. There can be important differences between the submitted version and the official published version of record.

People interested in the research are advised to contact the author for the final version of the publication, or visit the DOI to the publisher's website.

- The final author version and the galley proof are versions of the publication after peer review.

- The final published version features the final layout of the paper including the volume, issue and page numbers.

Link to publication

\footnotetext{
General rights Owners
rights.

- You may freely distribute the URL identifying the publication in the public portal. please follow below link for the End User Agreement:

www.umlib.nl/taverne-license

Take down policy

If you believe that this document breaches copyright please contact us at:

repository@maastrichtuniversity.nl

providing details and we will investigate your claim.
}

Copyright and moral rights for the publications made accessible in the public portal are retained by the authors and/or other copyright owners and it is a condition of accessing publications that users recognise and abide by the legal requirements associated with these

- Users may download and print one copy of any publication from the public portal for the purpose of private study or research.

- You may not further distribute the material or use it for any profit-making activity or commercial gain

If the publication is distributed under the terms of Article $25 \mathrm{fa}$ of the Dutch Copyright Act, indicated by the "Taverne" license above, 


\title{
Explaining variation in the role of the EU Council Secretariat in first and second pillar policy-making
}

\author{
Hylke Dijkstra
}

2010

This is an electronic version of an article published in the

Journal of European Public Policy 17(4), pp. 527-544.

\begin{abstract}
This article explains variation in the role of the Council Secretariat in first and second pillar policymaking. While the Council Secretariat started in both pillars as a facilitator of decision-making, it has been delegated additional tasks in foreign policy: from providing content expertise to representation. Such functions would normally have gone to the European Commission, yet in the sensitive domain of foreign policy the member states have preferred their own secretariat. This has implications in terms of agency. Due to its additional tasks, the Council Secretariat has more bureaucratic resources in the second pillar. While its activities furthermore used to be restricted to the decision-making phase, it is now also playing a role in the agenda-shaping and implementation of European foreign policy. These additional bureaucratic resources and opportunities not only impact on the Council Secretariat's political influence in the second pillar, but also on its strategies to promote its preferences.
\end{abstract}

\section{Keywords}

Common Foreign and Security Policy, Council Secretariat, delegation, European Union, principalagent, rational choice institutionalism

\section{INTRODUCTION}

It took scholars fifty years before they dedicated a full article to the role of the Council Secretariat in European Union (EU) policy-making; and despite some recent attention (Beach 2004; Christiansen 2002; Christiansen and Vanhoonacker 2008; Dijkstra 2008) the work of its 3400-plus civil servants remains underexplored. ${ }^{1}$ It sometimes seems that this is exactly the intention of the Council Secretariat, which tries to protect its impartiality by deliberately staying outside the limelight. Instead of putting itself to the fore, it has preferred to be the éminence grise to the Presidency in the first pillar and to leave the talking to the country in the chair. The Council Secretariat in the second pillar is, however, not gun shy. Since the Amsterdam Treaty (1999), it has been the home of the High Representative for the Common Foreign and Security Policy (CFSP) and Javier Solana as well as his senior officials have been rather outspoken. Apart from making a contribution to the public debate, officials from the Council Secretariat also actively take the floor in the Council.

1 The General Secretariat of the Council of the European Union, as it is formally called, was founded in 1952. The staff figure is from the 2009 EU General Budget. 
This article tries to explain the variation in the roles of the Council Secretariat across both pillars. In line with rational choice institutionalist accounts of European integration, it argues that there are multiple reasons for the delegation of tasks to supranational institutions. The Council Secretariat, in this respect, started in both pillars from the same basis: to reduce the negotiation costs of co-operation. Yet as the CFSP grew more complex during the 1990s, the member states delegated additional tasks to the Council Secretariat, ranging from content expertise to collective representation. In the first pillar such functions would normally have gone to the European Commission, but in the sensitive domain of foreign policy the sovereignty-wary member states preferred their own secretariat over the resource-rich and formally autonomous Commission.

That the Council Secretariat has been delegated additional tasks in the CFSP has obvious implications in terms of agency. With regard to bureaucratic resources, it previously possessed considerable 'process expertise' in both pillars, but now it also has acquired some 'content expertise' in the field of the CFSP. While its activities furthermore used to be restricted to the decision-making phase, due to its new responsibilities the Council Secretariat is now playing a role in the agenda-shaping and implementation of foreign policy as well. These additional bureaucratic resources and opportunities in the CFSP improve the possibilities for the Secretariat to assert political influence. This article will first provide a theoretical overview and will subsequently discuss the role of the Council Secretariat in both pillars empirically.

\section{DELEGATION, BUREAUCRATIC RESOURCES AND OPPORTUNITIES}

\section{Rationale for delegation}

When analysing the bureaucratic resources of an agent, it is important to identify the initial rationale behind the delegation. Since rational choice institutionalists see the delegation of tasks to an agent in terms of functional needs based upon a careful cost-benefit analysis (e.g., Keohane 1984; Pollack 1997; Thatcher and Stone Sweet 2002), these reasons are critical as they determine to a large extent the institutional setting, in which the agent operates, and the bureaucratic resources it has at its disposal. Agents are created to carry out particular tasks - because they can do it better or cheaper than the principals - and they are designed to do their job. After identifying the initial rationale for delegation, more precise hypotheses can be formulated concerning the institutional design and potential political influence of the agent (Pollack 1997, 2003). While there are all sorts of good reasons for principals to delegate tasks, in the study of the EU institutions the emphasis has been on the member states trying to reduce their transaction costs of co-operation. These transaction costs vary in the different phases of the policy cycle.

During the agenda-setting phase there is the risk of cycling and overcrowded or underdeveloped agendas (Tallberg 2006). This problem can be dealt with by delegating the right of initiative to supranational institutions or a chairmanship. The decision-making phase in the EU furthermore entails a large number of negotiations taking place on a daily basis with thousands of diplomats from different national ministries, requiring office management, translation and distribution of documents, as well as co-ordination, leadership and brokerage. Supranational institutions can play an important role here due to their permanent presence, continuity and institutional memory. In addition, the member states face information costs during the decisionmaking phase depending on the complexity of the policy area. Epstein and O'Halloran (1999) have shown that there is a need for information in agriculture, finance and environment, as well as security and defence policies. Supranational expert bureaucracies can reduce these costs, since having a centralized bureaucracy is generally cheaper than 27 bureaucracies across the member states. Another advantage is that supranational expert bureaucracies can provide relatively unbiased information (Abbott and Snidal 1998). A commonly agreed information base is especially important for efficient decision-making in divisive policy areas.

The implementation phase has been mostly studied in the context of delegation. The credible commitment problem, in particular, stands out. After an agreement has been reached, proper 
implementation or domestic compliance is, after all, not guaranteed. Supranational institutions can help to reduce these costs by being a neutral monitor and enforcer of the treaties (Pollack 1997, 2003). In a bounded rational world, every complex agreement is furthermore incomplete (Williamson 1985). The member states cannot lay down all the details in the treaties or secondary legislation, which can eventually lead to non-compliance, if some member states block the process at a later stage. Moravcsik (1998) has shown that member states, in order to enhance credible commitments, therefore either pool or delegate some of their sovereignty to structure future incentives. The delegation of executive tasks to the Commission in the field of competition policy is an example. As compliance problems and incomplete contracting take place in a divisive distributive environment, there is the need to formalize these credible commitments and to give supranational institutions significant autonomy (Tallberg 2000, 2002).

Delegating tasks to a supranational implementing executive not only takes place for the purpose of credible commitments, but can also result from an efficiency effort to relieve the member states from over-involvement in the details (Majone 2001). Contrary to the credible commitment problem, the member states are more likely to create such an efficient implementing executive when issues are relatively non-divisive. As a result these implementing executives are unlikely to hold significant autonomy (Majone 2001). Similarly to much of the delegation in the agenda-setting and decision-making phase, these institutions only facilitate the member states in their daily work and as such provide efficiency gains for all. Finally there is a demand for collective representation, as EU negotiations often have an impact on agreements with external actors (Tallberg 2006). Representation through 'one voice' - either a chairmanship or supranational institution - is generally more efficient than member states going at it individually.

Since the policies of the EU are diverse, there is a variation in the functional needs of member states across the pillars. Because foreign policy co-ordination is generally a reactive exercise, agenda-setting powers are of less importance in the second than in the first pillar. The CFSP agenda is therefore likely to be structured through informal management arrangements than via formal rules. The negotiation costs of decision-making are, on the contrary, relevant in both pillars: in the first pillar due to the amount of negotiations; in the second pillar as a result of its high-velocity character. Informational input is required in various first pillar areas and in foreign policy as well. Credible commitments, on the other hand, are not a major concern in the CFSP. Because member states have chosen a particular institutional structure in the second pillar - the coordination of foreign policies over, for example, a federalization - non-compliance is not an issue (Wagner 2003). The sovereignty-wary member states have furthermore decided not to address the issue of incomplete contracting in the CFSP, but rather to co-ordinate again when necessary. With the arrival of the European Security and Defence Policy (ESDP, 1999), the need for an efficient implementing bureaucracy has become as pertinent in the CFSP as it is in the first pillar. Finally, both pillars require external representation.

Given such variation in functional needs in both pillars, it is interesting to look at the division of labour between the Commission and the Council Secretariat - the two 'supranational executives'. This article will empirically show below that the Council Secretariat was created in the first pillar to reduce the negotiation costs of co-operation. Agenda-setting, informational input, credible commitments and representation went to the Commission (and its agencies and the Court of Justice). In the second pillar, the Council Secretariat reduces the negotiation costs of co-operation as well. Yet, for other functional demands, the member states have divided tasks differently. Because credible commitments were not a major concern, the member states could comfortably keep the resource-rich and formally autonomous Commission at arm's length. As European foreign policy grew more complex, they therefore delegated informational tasks instead to the Council Secretariat. Executive implementing functions in the CFSP were mostly given to the Council Secretariat. The tasks of informal agenda-setting and collective representation were initially delegated to the Presidency, but later also to the Council Secretariat. The Commission has a shared right of initiative. Table 1 gives an overview of these functions. 


\begin{tabular}{|l|l|l|l|}
\hline \multicolumn{2}{|l|}{ Table 1 Delegation to the Commission and Council Secretariat } \\
\hline Phase & Functional demand & First pillar & Second pillar \\
\hline Agenda-setting & Stable agenda & Commission & Commission / Secretariat* \\
\hline Decision-making & $\begin{array}{l}\text { Efficient process } \\
\text { Information / expertise }\end{array}$ & $\begin{array}{l}\text { Secretariat } \\
\text { Commission }\end{array}$ & $\begin{array}{l}\text { Secretariat } \\
\text { Secretariat }\end{array}$ \\
\hline Implementation & $\begin{array}{l}\text { Credible commitments } \\
\text { Efficient executive } \\
\text { Collective representation }\end{array}$ & $\begin{array}{l}\text { Commission } \\
\text { Commission } \\
\text { Commission }\end{array}$ & $\begin{array}{l}\text { Secretariat* } \\
\text { Secretariat* }\end{array}$ \\
\hline$*$ The Council Secretariat performs these tasks under formal guidance of the Presidency and Council. \\
\hline
\end{tabular}

\section{Bureaucratic resources of EU institutions}

Because institutions are designed to do their job, their bureaucratic resources closely relate to the rationale for delegation. Resources consist, firstly, of formal competences. Yet, as the Council Secretariat was not created for the purpose of credible commitments, its formal competences are limited. In addition, bureaucratic resources consist of informational surpluses. Typically bureaucrats are better in assessing their own diligence when dealing with a delegated task than their political principals (Arrow 1985). Supranational civil servants with an informational advantage can furthermore help member states to reach additional gains - if negotiations are not Pareto-efficient by taking on an advisory role and meanwhile pursuing a distribution closer to their private interests. The question is thus what these informational asymmetries are and how they relate to the rationale for delegation.

Civil servants in supranational institutions, which mitigate negotiation costs, normally accumulate 'process expertise' (e.g., political, negotiation, procedural) over time and information on the state-of-play of negotiations (Beach 2005; Metcalfe 1998; Tallberg 2006). Due to their longerterm involvement, continuity and institutional memory, they have a good overview of the historical preferences of member states. Because they are at the core of the machinery, through their interaction with the Presidency and the (confidential) bilateral contacts with key member states, they know precisely at what stage a proposal is during the negotiation process. As 'guardians of the orthodoxy' they also have the authority and reputation to point the member states at how to make best use of the rules of the game. While these civil servants do not have a monopoly on negotiation skills, they thus have structural advantages over the Presidency and the member states.

Civil servants in expert bureaucracies, who provide the member states with information, do not hold these informational advantages. Rather, they post their policy recommendations at particular moments in time and thus do not have much process expertise or information on the stateof-play. Rather, they have 'content expertise' (e.g., policy, technical, legal). Since outsourcing implies that one no longer performs the tasks 'in-house', the administrative capacity of the member states is normally reduced out of efficiency considerations. The notion of expert bureaucracies has recently been under pressure in some rationalist theories. The numbers of supranational civil servants in Brussels, it is argued, tend to be smaller than in the capitals (e.g., Pollack 2003). Apart from the fact that this observation is sometimes incorrect (see below), and that numbers in themselves do not always mean much, it is clear that officials in the Commission generally know more about the collective legislation of all the member states than experts of the individual countries. 


\section{Opportunities in the policy cycle}

Supranational institutions will only be tempted to use their informational asymmetry in case of a goal conflict with the member states. While Kiewiet and McCubbins (1991: 5) confidently assume that 'there is almost always some conflict between the interests of those who delegate authority (principals) and the agents to whom they delegate it', it seems nonetheless a good idea to identify what the Council Secretariat really wants. It is, in this respect, possible to differentiate analytically between competence-maximizing (Majone 1996) and policy-seeking interests. These preferences are often complementary (pro-environment policy leads to more competences for the DirectorateGeneral for Environment), but there can also be a trade-off. For a supranational institution to perform brokerage to overcome a stalemate in the negotiations requires a relatively neutral reputation. Yet, the active promotion of policy preferences endangers such reputation. It is therefore likely that the Council Secretariat in the first pillar, which is only to a limited extent engaged with the substance of policy, will focus on its competence-maximizing preferences. The Council Secretariat in the second pillar is more extensively engaged with the substance and will thus have to balance between its interests.

While the incentive to pursue private interests is thus almost always present, it is also a question of whether opportunities actually arise. In the implementation of delegated tasks, the agent's discretion correlates with the informational asymmetries and the control mechanisms (Arrow 1985). With regard to actual decision-making, informational asymmetries do not automatically transform into political influence; the supranational civil servants also require access to the political power-holders in order to convince them. Whether the member states actually delegate tasks for implementation to the civil servants in the Council Secretariat and whether civil servants are being granted access very much depends in a repeated game on reputation. Furthermore, while the Council Secretariat in the first pillar is only active during the decisionmaking phase of the policy cycle, as a result of its delegated tasks, there are also opportunities for the Council Secretariat during the agenda-setting and implementation of foreign policy (putting initiatives forward and making them happen).

Table 2 Expected bureaucratic resources, goal conflicts and opportunities in the policy cycle of the Council Secretariat.

\begin{tabular}{|l|c|c|}
\hline & First pillar & Second pillar \\
\hline Bureaucratic resources & & \\
Process expertise & $\mathrm{X}$ & $\mathrm{X}$ \\
Content expertise & $\mathrm{X}$ & $\mathrm{X}$ \\
State of play & & $\mathrm{X}$ \\
\hline Preferences and interests & $\mathrm{X}$ & $\mathrm{X}$ \\
Competences & & $\mathrm{X}$ \\
Policy-seeking & & $\mathrm{X}$ \\
\hline Opportunity in the policy cycle & & $\mathrm{X}$ \\
Agenda-setting & $\mathrm{X}$ & \\
Decision-making & & \\
Implementation & & \\
\hline
\end{tabular}

Whether supranational institutions can exercise political influence lastly depends on the availability of control mechanisms. If effective monitoring prevents the agent from shirking, its political influence in the end is minimal. While the principal-agent literature is full of examples of control mechanisms to limit agency during policy implementation (e.g., McCubbins et al. 1987; McCubbins and Schwartz 1984), it is more complicated when the agent takes on an advisory role. Obviously, the principal can disregard the advice in case of lack of trust, but objectively evaluating the information is difficult. Furthermore, within EU bureaucracy punishing the agent ex post is 
often hardly possible, because the principals tend to disagree. If control mechanisms are identified, they are likely to be ex ante and deal with incentives to prevent goal conflicts in the first place.

\section{COUNCIL SECRETARIAT IN THE FIRST PILLAR}

The remainder of this article will discuss the empirical evidence. It analyses the first and second pillars separately. However, before going to the institutional structures in these pillars, it is useful to point at the limited formal competences of the Council Secretariat in the Treaties (s ee Table 3).

Table 3 The Council Secretariat in the Treaties (adjusted by the author)

First pillar: article 207(2) Treaty establishing the European Community

- The Council shall be assisted by a General Secretariat ... The Council shall decide on the organisation of the General Secretariat.

Second pillar: articles 18(3), 26 Treaty on European Union

○ The Presidency shall be assisted by the ... High Representative.

○ The High Representative ... shall assist the Council ... within the scope of the [CFSP], in particular through:

- $\quad$ Contributing to the formulation, preparation and implementation of policy decisions;

- Acting on behalf of the Council at the request of the Presidency.

\section{Rationale for delegation}

The Council Secretariat was created in 1952 'to assist the Council' (Rules of Procedure 1952, article 11) and its 'initial staffing levels [were to] be kept to the minimum number strictly necessary' (Council 1952, article V), which points in the direction of a cost-benefit analysis. For the organization of the Secretariat, the models of the Benelux and League of Nations secretariats were considered (Memorandum to the Secretary, September 1952), but this was not deemed adequate for the needs of the member states. By furthermore remaining in charge of the organization of the Secretariat (Rules of Procedure 1952, article 12), the Council had strict control over bureaucratic expansion. The Council Secretariat was thus intentionally designed. In contrast to the High Authority and the Court of Justice (Pollack 2003), the Secretariat was not created for credible commitments. It was supportive.

The Council Secretariat has come a long way since the early days of European integration. Its staff has increased from the initial 30 to over 3,000 officials (Hayes-Renshaw and Wallace 2006). Over time it took on new roles, such as an 'honest broker' in the negotiations among member states, particularly after the 'empty chair' crisis (1966) had compromised the Commission's impartiality. Through its continuity and institutional memory, it also became the chief political advisor to the Presidency (Westlake and Galloway 2004). And yet, despite all these new roles, it is surprising that while the Rules of Procedures have become much more detailed over the decades, the articles on the Council Secretariat have remained more or less the same.

The Council Secretariat's main responsibility in the first pillar has remained 'to create the conditions for a smooth running of the Council machinery' (Christiansen and Vanhoonacker 2008: 756; see also Hayes-Renshaw and Wallace 2006; Westlake and Galloway 2004). The new roles and the increase in personnel reflected the increasing complexity of the European Union and the need of the member states for efficient decision-making. The important learning effect for the member states, and particularly for the Presidencies, has been that involving the Council Secretariat leads to higher efficiency gains and to lower negotiation costs. 


\section{Bureaucratic resources}

The Council Secretariat's relevance in the first pillar can probably be best put in numbers. Among its tasks is the organization of the Council's work. This includes the 'producing, translating, distributing and archiving' annually of almost 100,000 documents and 100 million copies (HayesRenshaw and Wallace 2006: 113). To guarantee efficiency, the Council Secretariat has formalized its procedures for circulating the agenda, documents and silence procedures. Furthermore, the vertical and horizontal co-ordination in the Council gives the Secretariat a key position in the decision-making web. Only its minutes are official and on the basis of these minutes the Council Secretariat writes the cover notes, outlining the major discussions, which accompany draft legislation across the Council and European institutions.

To provide more evidence of what these tasks mean in terms of the Council Secretariat's bureaucratic resources, it is interesting to point at the Report of the 'Three Wise Men' on the European Institutions. Already, in 1979, they concluded that the Council Secretariat 'possesses a knowledge of procedures, an overall view of the machinery, and an opportunity for neutral assessment of the other States' attitudes which even the largest national administration cannot match' (Committee of Three of the European Council 1979: 34). Given the above-mentioned increase in personnel, this statement is even more relevant today. Over time the Council Secretariat has accumulated process expertise due to its continuity vis-à-vis the rotating diplomats and its institutional memory. As a result of its key position in the co-ordination of EU decision-making, it has an excellent overview of the state-of-play.

Since the Council Secretariat has so much process expertise, it seems a natural ally for the Presidency. But this has come with a cost. In addition to its traditional roles (logistics provider, record keeper, and purveyor of legal advice), the Secretariat has furthered its bureaucratic interests - often at the expense of the Presidency - by taking on the previously mentioned new roles (e.g., Christiansen 2002; Christiansen and Vanhoonacker 2008; Hayes-Renshaw and Wallace 2006; Westlake and Galloway 2004). It is exactly these roles, carried out by officials at diplomatic level, which have recently provided the Council Secretariat with more process expertise, knowledge about the state-of-play and possible informational asymmetries. The dependency of member states has thus increased.

While a number of these new tasks are important and while the process expertise is significant, it must also be emphasized that the Council Secretariat's expertise in the first pillar is not exclusive. Diplomats know how to run negotiations and to co-ordinate between different levels as well. Moreover, much depends on the preparation of the Presidency and its willingness to get the Council Secretariat involved. Lastly, some observers (e.g., Tallberg 2006) have noted that officials from Council Secretariat also gain content expertise while working on a dossier. Although this is probably true, such content expertise is very limited compared to the expertise of the Commission in the first pillar. Leadership based on content expertise alone is thus unlikely to come from the Council Secretariat, but it can strengthen its position versus the Presidency.

\section{Opportunities in the policy cycle}

At the surface the Council Secretariat presents itself as an impartial actor. As a senior official once put it, 'I don't mind whether [the member states] decide to paint the room black or white, as long as the decision is taken in the correct way' (quoted in Schout and Vanhoonacker 2006: 1054). While staying neutral might not be the Council Secretariat's default value, it is clear that it attaches less importance to its substantive preferences than to competence-maximizing. Maintaining an impartial reputation is its strategy to acquire the 'more important' roles it cherishes (i.e., being an 'honest broker'; providing political advice; a 'good offices' mediator). The profile of the competencemaximizer is empirically supported by Christiansen (2006) and Beach (2004, 2007). The relationship with the Presidency also needs to be mentioned. While this is often its de facto principal (Beach 2007), its formal principals are the member states. Former Secretary-General Ersbøll (1992), in this respect, stated that 'our master is the Council ... we have ways of acting as a 
brake on national Presidency initiatives if ever they should take on an excessive national colouring' (quoted in Westlake and Galloway 2004: 350). This obviously helps the Council Secretariat's reputation as an honest broker.

The windows of opportunities for the Council Secretariat in the first pillar to use its process expertise in order to further private interests are restricted to the decision-making phase of the policy cycle. Once the Commission - having the exclusive right of initiative - has tabled a proposal, the Secretariat gets involved. After legislation has been adopted, it is up to the Commission and the member states to implement it. Only when cases are referred to the Court of Justice does the Council Secretariat's legal service have an important presence in terms of representing the Council. Given its general pro-Council preferences, as well as the aim for legal purity, no agency costs are involved for the member states during this stage.

In the decision-making phase, however, the Council Secretariat is involved from the beginning to the very end. After the Commission has tabled its draft, the Secretariat provides the Presidency with political advice on which strategies to take using its institutional memory with regard to previous national preferences. Following the deliberations of the working groups, the Council Secretariat sends a 'note to working party members' accompanying the redrafted text (Hayes-Renshaw and Wallace 2006). This note includes the major positions of the member states on the outstanding paragraphs. When the draft moves up to the Committee of Permanent Representatives (COREPER), the Council Secretariat writes a similar cover note 'to COREPER from the working party' and a strategic confidential document 'to the chair of COREPER from the Secretariat', which may include speaking notes (Hayes-Renshaw and Wallace 2006). These documents contain phrases such as "the Poles are isolated" ... "a possible vote has been signalled"" (Nugent 2006: 203). The same procedure applies when the draft moves up to Council. Through this system of notes, any Presidency becomes dependent on the Council Secretariat and such access is helpful when maximizing its competences.

Since few dossiers in the first pillar are concluded under the leadership of one Presidency, the Council Secretariat also has a role to play through briefing the incoming Presidency (Nugent 2006). As the officials of the Secretariat have been so closely involved in the process, incoming Presidencies often rely on its information regarding the state-of-play of the negotiations. The Council Secretariat has been active as well, as stated above, in slowing down the pet projects of Presidencies, by pointing them at the long agenda of unfinished and ongoing work. Fully stopping ambitious Presidencies is obviously not in its powers. The Council Secretariat's influence will always be limited to the extent that the Presidency allows it to play a role.

Apart from providing strategic advice to the country in the chair, the Council Secretariat also takes a proactive, though behind-the-scenes, approach in the negotiations. The Council Secretariat is particularly important when negotiations get very difficult during the end-game. Together with the Presidency it often plays the role of an 'honest broker' due to its perceived neutrality. In most cases it is the Secretariat rather than the Presidency which comes up with the compromise (Sherrington 2000: 166). Commission officials clearly prefer such a Brussels-drafted rather than capital-drafted compromise, because apart from the Presidency's private interests, quickly finalizing a draft before the end of the Presidency often leads to lowest common denominator agreements (interview Commission official, 2008). It goes without saying that the 'power of the pen' increases the dependence of member states on the Council Secretariat.

While the intense involvement of the Council Secretariat in the decision-making phase creates room to increase its own role and informal competences, it is still up to the member states to decide to what extent they rely on the Council Secretariat. This seems to be the major control mechanism. Some Presidencies have been more reluctant than others to use the Secretariat (e.g., Christiansen 2002; Elgström 2003; Schout and van Vanhoonacker 2006). Its opportunity to maximize its role thus varies depending on its access to the formal power holders. While many national representatives in COREPER are aware of the added value of the Secretariat, ministers in the national capitals sometimes prefer to rely on their personal advisers (Nugent 2006). 


\section{COUNCIL SECRETARIAT IN THE SECOND PILLAR}

\section{Rationale for delegation}

The sensitivities of foreign policy can hardly be overstated when discussing delegation in the second pillar. Not only have the member states kept the Commission at arm's length since the initiation of foreign policy co-operation (1970), they also originally preferred to keep the secretarial tasks 'in-house' by delegating them to the Presidency (Nuttall 1992). Three years after the start of foreign policy co-operation, the member states nonetheless noted that 'experience has also shown that the Presidency's task presents a particularly heavy administrative burden' (Copenhagen Report 1973: article 8); yet they did little to reduce it. The delegation costs were apparently higher. Only with the Single European Act (1987), a small-scale Brussels-based Secretariat was finally established to 'assist the Presidency' with administrative functions (article 30(10) $(\mathrm{g})$ ). With the Maastricht Treaty, this Secretariat was strengthened and integrated in the Council Secretariat. It became known as the 'CFSP unit'.

When, during the 1990s, the Commission was not forthcoming with policy proposals under its newly gained shared right of initiative, the Presidency increasingly started to look at the Council Secretariat for content expertise (Dijkstra 2009). In a reaction to the Bosnian and Kosovo wars, the member states further strengthened the Council Secretariat under the Amsterdam Treaty (1999) with the High Representative and the Policy Unit in Brussels and with EU Special Representatives on the ground. This was meant to make the CFSP 'more effective, coherent, and visible' (Vanhoonacker 1997: 7). According to the report by the Reflection Group (1995), which prepared the Treaty, the Policy Unit could ensure, during the 'preparatory phase' of policy-making, 'the necessary follow-up to crisis situations' and prepare 'possible response and decision options'. In the final Treaty, one of the Policy Unit's tasks is to produce 'argued policy options papers' (Declaration annexed to Amsterdam Treaty). The Special Representatives represent the European Union on the ground and report to the High Representative. The member states were thus filling the gap left by the relative absence of the Commission in the CFSP (Dijkstra 2008).

As a result of the Helsinki and Nice European Councils (1999, 2000), which created ESDP, the Council Secretariat also became the European Union's source of military expertise through the establishment of the EU Military Staff (EUMS). This body currently employs 200-plus military officers. It does not act as a fully fledged implementing executive, but rather supports the member states in day-to-day ESDP decisions. When the EU is not engaged, it provides early warning and monitors potential crises. In crisis management situations, it handles intelligence, provides situation assessment and military strategic options to the member states, and co-ordinates with national planning staffs that might participate in EU-led operations. During the operations themselves, the EUMS assists the Operation and Force Commanders. Since 2007, the Council Secretariat is also the basis of the Civilian Planning and Conduct Capability (CPCC), which performs similar functions in civilian crisis management. For intelligence-sharing, it has a Joint Situation Centre (SITCEN).

\section{Bureaucratic resources}

The Council Secretariat has accumulated process expertise in the CFSP in a similar fashion as in the first pillar. Because it initially did not have a long foreign policy tradition and since second pillar dossiers differ substantially from those of the first pillar, this has taken some time. On the other hand, the Council Secretariat has been at the forefront of developing the crisis management procedures in ESDP. This has led to significant process expertise. Acquiring strategic information on the state-of-play is similar to the first pillar as well. Yet, due to the relatively weak role of the Commission, the Council Secretariat and the Presidency have an even more powerful position in the second pillar (Duke and Vanhoonacker 2006). Importantly, the Council Secretariat already gets involved during the agenda-setting phase and has an important role to play in implementation (see below). This gives it an even better overview of the state-of-play.

The relative absence of the Commission in the second pillar also has an effect on the Council Secretariat's content expertise. As described above, the civil servants of the Council 
Secretariat have become the Presidency's major source of policy expertise in Brussels. On a daily basis the Presidency draws on the expertise of more than 150 civil servants in the DirectorateGeneral for External Relations (DG E). Solana furthermore receives direct input from the Policy Unit - nowadays almost integrated in DG E - consisting of 30-plus seconded national officials. Particularly in the very political areas, where the presence of the Commission has traditionally been weak or non-existent, the Council Secretariat has strong content expertise. As far as informationgathering is concerned, the Council Secretariat is still heavily dependent on the input of the member states, apart from the regular fact finding missions and briefings from the EU Special Representatives. It does not have a permanent external or intelligence service.

The Council Secretariat's military expertise in the ESDP furthermore deserves special attention. Apart from the creation of the EUMS, CPCC and SITCEN, the Secretariat became the basis of two substantial directorates, dealing with civilian and military affairs. In total it currently employs over 400 officials, who support the member states during the decision-making and implementation for ESDP operations. In terms of numbers, there are no member states with so much specific policy expertise. With the creation of the independent Operation Centre (2007) within the EUMS, the Council Secretariat might furthermore in the future be in charge of carrying out the complete implementation of ESDP operations. These services were explicitly created as expert bureaucracies and they are functioning as such. They provide the member states with most of the relevant military information during the decision-making phase and support the member states with information when actually implementing ESDP missions.

\section{Opportunities in the policy cycle}

That the competence-related interests of the Council Secretariat in the second pillar can lead to goal conflicts has become obvious during various conflicts with the Commission and several member states (Crowe 2003; Dijkstra 2009; Spence 2006). In filling the above-mentioned informational gap, the Council Secretariat quite naturally met the Commission on its way. The Council Secretariat's preferences in the second pillar, however, go beyond competence-maximizing. Various examples are the repeated pleas by Solana to build up stronger military capabilities and well as the notion of 'pre-emptive action' promoted by Robert Cooper, the Director-General for External Relations. Such interest in military capabilities is in conflict with the preferences of a number of member states. This became evident during the negotiations on the European Security Strategy (2003), where the member states watered down the initial proposals.

Quite clearly, there is much overlap between these competence and substantive preferences. More emphasis on military resources (rather than civilian power) implies a more central role for the Council Secretariat in foreign policy-making. Yet, the fact that Solana and his civil servants express their opinions on the role, the scope and the identity of the European Union in the world, as well as on the future road to be taken, and actively promote these preferences distinguishes the Council Secretariat's foreign policy services from those of the first pillar. It is, for example, hard to imagine civil servants in the first pillar trying to promote a more social or liberal Europe. These are generally not the preferences on which first pillar civil servants are acting.

The scope for opportunities to gain private interest is also larger in the second than in the first pillar. In the CFSP the Council Secretariat is involved in setting the agenda and in implementing agreed policy under the guidance of the Presidency. In the agenda-setting phase, the political profile of the High Representative is crucial. By simply visiting countries or regions, Solana can turn the eye of world media at particular issues he deems important. It was telling, for example, that Solana was the first governmental leader to visit the Middle East after conflicts broke out in Lebanon (2006). He furthermore ensured that the issue did not leave the European agenda and persuaded major European countries, such as Italy and France, to make up the backbone of the United Nations peacekeeping operation. Similarly he played an active role during the conflict in Macedonia (2001).

In the decision-making phase, it is the Council Secretariat, which drafts most of the common positions in the CFSP. These documents range from simple statements to complicated joint actions 
and operational plans for military missions. The member states obviously decide, but writing the drafts matters. It is worth noting that during the political decision-making phase, national diplomats often have too little military expertise. That is why they rely heavily on the EUMS, which was conceived as the main military planning body. The EUMS thus moves up the policy cycle and the Council Secretariat can apply its informational asymmetry when it comes to decide on matters of a political nature. It is furthermore important to note that time pressures in the CFSP are particularly high. The civilian observation mission in Georgia (2008) was, for example, planned in five days after the formal agenda-setting. Such time pressures limit the information processing capabilities of the national diplomats.

During the implementation phase, the Council Secretariat plays a role along with the Presidency and the member states. Following the Treaties, the High Representative can be asked to represent the European Union. In these cases the Council Secretariat can exercise hidden action. In addition, the Council Secretariat acts as the liaison between the chain of command of ESDP missions and the member states. This is important during the detailed planning of an operation, its force generation, launch and the actual implementation. Its actions are ex post supervised and approved by the Political and Security Committee, a member states' body in the Council.

\section{CONCLUSION}

This article has shown that the rationale for delegation to the Council Secretariat differs in the first and second pillar. In the first pillar, it reduces the negotiation costs of co-operation, while in the second pillar it was delegated additional responsibilities. Such difference in delegation can be explained by the sensitive nature of foreign policy and the variation in functionalist demands across both pillars. Rather than delegating informational, executive and representational tasks to the autonomous and resource-rich Commission, the member states have preferred their own secretariat in the CFSP. This article has also shown that the different rationales for delegation have a subsequent effect on the Council Secretariat's resources and opportunities in the policy cycle. In addition to its process expertise, it possesses content expertise in the second pillar. While the Council Secretariat in the first pillar is furthermore only active during the decision-making phase, it plays an important role in the agenda-setting and the implementation of the CFSP as well.

What does this imply for the behaviour of the Council Secretariat and the strategies that it pursues in both pillars? Because the Council Secretariat in the first pillar takes an interest in expanding its competences in the decision-making phase (it prefers the more exciting role of brokerage over minute-writing), its objective is to have the Presidency and the member states make more extensive use of its services. They will, however, only ask the Council Secretariat if it upholds its impartial reputation and shows that it provides its principals with higher payoffs. There is thus an incentive to stay quiet and operate behind the scenes. In the second pillar many of these points apply as well during the decision-making phase. The Council Secretariat needs the member states. Yet its additional tasks have given it a more ambitious role, which implies that civil servants will have to defend their proposals in the working groups, that Special Representatives have to explain the EU's position in third countries, and that the High Representative is seen as the face of European foreign policy. These tasks cannot be done behind the scenes.

At the time of writing, the member states and the institutions were busy discussing the implementation of the Lisbon Treaty. In Baroness Ashton the member states have appointed a former Trade Commissioner, and she has made clear that her office will be physically located in the Commission. It is also clear that much of the foreign policy staff of the Council Secretariat including most of DG E, the Policy Unit, EUMS, CPCC and SITCEN - will be transferred to the European External Action Service. This is a new sui generis institution, over which member states have full control in terms of organization. The Secretariat will thus lose much of its content expertise. It will retain some 50 civil servants, who will service the foreign policy working groups in a similar fashion as the Secretariat is supporting the first pillar working groups. In this sense, it will again become more of a traditional secretariat, focusing on the efficiency of decision-making. 
Biographical note: Hylke Dijkstra is a Ph.D. candidate at the Faculty of Arts and Social Sciences of Maastricht University, The Netherlands.

Address for correspondence: Hylke Dijkstra, Maastricht University, Faculty of Arts and Social Sciences, P.O. Box 616, 6200 MD, Maastricht, The Netherlands.

\section{ACKNOWLEDGEMENTS}

The author would like to thank Derek Beach, Tannelie Blom, Thomas Christiansen, Bernard Steunenberg, Sophie Vanhoonacker, Esther Versluis and two anonymous referees for their comments.

\section{REFERENCES}

Abbott, K. and Snidal, D. (1998) 'Why states act through formal international organizations', Journal of Conflict Resolution 42(1): 3-32.

Arrow, K. (1985) 'The economics of agency', in J. Pratt with R. Zeckhauser (eds), Principals and Agents: The Structure of Business, Cambridge: Harvard Business School Press, pp. 37-51.

Beach, D. (2004) 'The unseen hand in treaty reform negotiations: the role and influence of the Council Secretariat', Journal of European Public Policy 11(3): 408-39.

Beach, D. (2005) The Dynamics of European Integration: Why and When EU institutions Matter, Basingstoke: Palgrave Macmillan.

Beach, D. (2007) 'Oiling the wheels of compromise: the Council Secretariat in the 1996-97 IGC and 2003 - 4 IGCs', in D. Beach with C. Mazzucelli (eds), Leadership in the Big Bangs of European Integration, Basingstoke: Palgrave Macmillan, pp. 76-93.

Christiansen, T. (2002) 'Out of the shadows: the General Secretariat of the Council of Ministers', Journal of Legislative Studies 8(4): 80-97.

Christiansen, T. (2006) 'Council of Ministers: facilitating interaction and developing actorness in the EU', in J. Richardson (ed.), European Union: Power and Policy-Making, London: Routledge, pp. 99-120.

Christiansen, T. and Vanhoonacker, S. (2008) 'At a critical juncture? Change and continuity in the institutional development of the Council Secretariat', West European Politics 31(4): 751-70.

Committee of Three of the European Council [Three Wise Men] (1979) 'Report on European institutions', ENA digital library, Sanem, Luxembourg: CVCE, available online at http://www.ena.lu

Copenhagen Report (1973) 'Second report on European political cooperation in foreign affairs matter', 23 July, EAM digital library, Sanem, Luxembourg: CVCE, available online at http://www.ena.lu

Council (1952) 'Minutes of the first meeting of the Council', 8-10 September.

Crowe, B. (2003) 'A common European foreign policy after Iraq?' International Affairs 79(3): 53346.

Dijkstra, H. (2008) 'The Council Secretariat's role in the Common Foreign and Security Policy', European Foreign Affairs Review 13(2): 149-66.

Dijkstra, H. (2009) 'Commission versus Council Secretariat: an analysis of bureaucratic rivalry in European foreign policy', European Foreign Affairs Review 14(3): 431-50.

Duke, S. and Vanhoonacker, S. (2006) 'Administrative governance in CFSP: development and practice', European Foreign Affairs Review 11(2): 163-82.

Elgström, O. (ed.) (2003) European Union Council Presidencies: A Comparative Perspective, London: Routledge.

Epstein, D. and O'Halloran, S. (1999) Delegating Powers: A Transaction Cost Politics Approach to Policy Making under Separate Powers, Cambridge: Cambridge University Press.

Hayes-Renshaw, F. and Wallace, H. (2006) The Council of Ministers, Basingstoke: Palgrave 
Macmillan.

Keohane, R. (1984) After Hegemony: Cooperation and Discord in the World Political Economy, Princeton, NJ: Princeton University Press.

Kiewiet, D. and McCubbins, M. (1991) The Logic of Delegation: Congressional Parties and the Appropriations Process, Chicago, IL: Chicago University Press.

Majone, G. (ed.) (1996) Regulating Europe, London: Routledge.

Majone, G. (2001) 'Two logics of delegation: agency and fiduciary relations in EU governance', European Union Politics 2(1): 103-22.

McCubbins, M., Noll, R. and Weingast, B. (1987) 'Administrative procedures as instruments of political control', Journal of Law, Economics, and Organization 3(2): 243-77.

McCubbins, M. and Schwartz, T. (1984) 'Congressional oversight overlooked: police patrols versus fire alarms', American Journal of Political Science 28(1): 165-79.

Memorandum to the Secretary (1952) 'Draft establishment plan for the Secretariat', 26 September.

Metcalfe, D. (1998) 'Leadership in European Union negotiations: the Presidency of the Council', International Negotiation 3(3): 413-34.

Moravcsik, A. (1998) The Choice for Europe: Social Purpose and State Power from Messina to Maastricht, Ithaca, NY: Cornell University Press.

Nugent, N. (2006) The Government and Politics of the European Union, Basingstoke: Palgrave Macmillan.

Nuttall, S. (1992) European Political Co-operation, Oxford: Clarendon Press.

Pollack, M. (1997) 'Delegation, agency, and agenda-setting in the European Community', International Organization 51(1): 99-134.

Pollack, M. (2003) The Engines of European Integration: Delegation, Agency, and Agenda Setting in the EU, Oxford: Oxford University Press.

Reflection Group (1995) A Strategy for Europe, 5 December, EAM digital library, Sanem, Luxembourg: CVCE, available online at http://www.ena.lu

Schout, A. and Vanhoonacker, S. (2006) 'Evaluating Presidencies of the Council of the EU: revisiting Nice', Journal of Common Market Studies 44(5): 1051-77.

Sherrington, P. (2000) The Council of Ministers: Political Authority in the European Union, London: Pinter.

Spence, D. (2006) 'The European Commission and the Common Foreign and Security Policy', in D. Spence with G. Edwards (eds), The European Commission, London: John Harper, pp. 356-95.

Tallberg, J. (2000) 'The anatomy of autonomy: an institutional account of variation in supranational influence', Journal of Common Market Studies 38(5): 843-64.

Tallberg, J. (2002) 'Delegation to supranational institutions: why, how, and with what consequences?' West European Politics 25(1): 23-46.

Tallberg, J. (2006) Leadership and Negotiation in the European Union, Cambridge: Cambridge University Press.

Thatcher, M. and Stone Sweet, A. (2002) 'Theory and practice of delegation to non-majoritarian institutions', West European Politics 25(1): 1-22.

Vanhoonacker, S. (1997) 'From Maastricht to Amsterdam: was it worth the journey for CFSP?' Eipascope 2(2): 6-8.

Wagner, W. (2003) 'Why the EU's Common Foreign and Security Policy will remain intergovernmental: a rationalist institutionalist choice analysis of European crisis management policy', Journal of European Public Policy 10(4): 576-95.

Westlake, M. and Galloway, D. (2004) The Council of the European Union, London: John Harper.

Williamson, O. (1985) The Economic Institutions of Capitalism: Firms, Markets, Regional Contracting, New York: Free Press. 